to New Zealand to observe the transit of Venus of 1874. While at the Antipodes he assisted the French to determine the longitude of the Campbell Islands. He returned to Fingland in 1875, and three years later was sent to Hong Kong as chief engineer of the Admiralty works. While there he designed a physical observatory for astronomical, magnetical, meteorological and tidal observations, and he made exact determinations of the position of the Hong Kong Observatory at Mount Elgin, Kowloon. In 1882, on his way home, he prepared a scheme for waterworks for Yokohama. This had been done at the request of the Japanese Government, and in 1885 he returned to the East to superintend the work. He also designed works for Osaka and Hakodate. He retired from the British Army in 1887 with the rank of major-general and died at Tokyo on March 10, 1893, at the comparatively early age of fifty-four years.

\section{Research on Influenza}

THE Medical Research Council has published a long report of the investigations made by Dr. C. $H$. Andrewes and his colleagues into the influenza epidemic of 1936-37 (Medical Research Council, Special Report Series, No. 228. London: H.M. Stationery Office, 1938. 2s. 6d. net). They have amply confirmed their previous discovery that there is an acute disease which may be properly called 'influenza', due to a virus which is specially infective for ferrets, and that many outbreaks of a somewhat similar kind are not associated with the virus; these they call "febrile catarrhs". Much attention was given to the possibility of diagnosing the real influenza by clinical means, and with a certain amount of success, though it is clear that accurate differentiation without demonstration of the virus is still rather uncertain. They have also confirmed the disconcerting American finding that all strains of the virus are not antigenically the same. Their plans for large-scale trials of preventive inoculation were anticipated by the epidemic, which came earlier than was expected and made a muddle of the experiments ; so far as they went, however, they did not show that inoculation was of any preventive value. Nor did the few cases which were treated with an anti-serum derive much benefit. In these respects, therefore, the results are disappointing, though a good deal has been done towards obtaining greater success in the outbreak which may be expected next winter.

\section{The Earthquake in Anatolia}

ON April 19, a destructive earthquake occurred in central Anatolia. Its epicentre lay near Kirshehir, about 90 miles south-east of Angora, and in this district ten villages were completely destroyed and at least 200 persons were killed. In Yozgad, about 60 miles north-east of Kirshehir, much damage was also caused, but the loss of life was small. The disturbed area extended from the Black Sea nearly to the Mediterranean. The first vibrations reached London at 12.11 p.m., and the earthquake must therefore have occurred shortly before 2.30 p.m., local time, when most of the inhabitants were at work in the fields. Since the beginning of the eighteenth century, not less than thirty-one great destructive earthquakes (of intensity 3, Milne scale) have occurred in Turkey in Asia, with one exception either in the west of the country about Smyrna and Broussa or in the east about Erzeroum and Diarbekr. The central portion of the country has been comparatively undisturbed. From Miss Bellamy's "Catalogue of Earthquake Epicentres" we find that during the years 1913-30 there were six earthquakes in three centres near Kirshehir and Yozgad, though none was strong enough to be recorded more than $80^{\circ}$ from the origin. In 1902, however, there was a destructive earthquake at Kastamonu, about 150 miles north of Kirshehir, of about the same intensity (degree 3) as the recent earthquake.

\section{The Magnetic Storm of April I6}

IN the note on the great magnetic disturbance of April 16 as recorded at Abinger Observatory, printed in NATURE of April 23, p. 721, it was only possible to give tentative estimates of the range in declination and horizontal intensity, for reasons then stated. Critical examination of the traces has since been made which confirms the estimate for declination but considerably reduces the figure given for horizontal intensity. The definitive ranges in the three elements are now stated, with the times of maximum and minimum, as below :

\begin{tabular}{|c|c|c|c|}
\hline $\begin{array}{l}\text { Declination (west) } \\
\text { Horizontal intensity } \\
\text { Vertical intensity }\end{array}$ & $\begin{array}{r}\text { Range } \\
5^{\circ} 7^{2} \\
1380 \gamma \\
494 \gamma\end{array}$ & 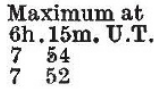 & 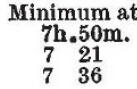 \\
\hline
\end{tabular}

\section{York Museum of "Bygones"}

The Castle Museum, York, of which the nucleus is the collection of Yorkshire "Bygones" formed by Dr. J. L. Kirk, of Pickering, was formally declared open by Lord Middleton, lord lieutenant of the East Riding, on April 23. The Museum is housed in the eightoenth century buildings, formerly the female prison, of York Castle, which, with the exception of the medieval Clifford's Tower, vested in H.M. Commissioners of Works under the Ancient Monuments Acts, is now in the possession and under the control of the Corporation of the City of York. The Corporation will be responsible for the maintenance of the Museum, and the sum of $£ 8,000$, in addition to two grants of $£ 500$ each from the Carnegie Trustees and the Rowntree Trustees, has been expended on the installation. The exhibits, including a Tudor half-timbered house and fifteen shop-fronts in two and three storied houses flanking a cobbled street, illustrate the life, domestic, commercial and industrial, of Yorkshire over a period of two centuries ending with mid-Victorian times. Among the more striking and characteristic features are old hearths and their furniture and old agricultural implements and horsebrasses. By a judicious arrangement with the former owner, the Corporation has retained the right to enlarge the collection with the view of making the exhibits illustrate as fully as possible the oldtime life of the folk of Yorkshire. An annexe, for example, is to be added shortly, which will house specimens of old and obsolete vehicles. As was pointed out at the opening ceremony by Dr. Mortimer Wheeler, 
president of the Museums Association, the Castle Museum is a valuable addition to the all too scanty collections, which illustrate the past social life of England.

\section{Science and the Home}

THE great variety of material that the glass industry is now able to place at the disposal of the architect and the builder is well demonstrated by the 'Glass Hall' erected in the Daily Mail Ideal Home Exhibition at Olympia, which closes on April 30 . The exhibits showed that in the hands of artistcraftsmen glass can be made a most effective medium of decoration. As regards the Glass House itself, the light-diffusing outer walls were made of fluted glass bricks permitting no observation from the outside. A partial vacuum inside renders them useful for the insulation as regards heat and sound. Each of the rooms of this house exhibits phases, useful and decorative, of the possibilities in glass, and the Crystal Kitchen has glass walls on two sides with the great merits of giving plenty of light and of being very easily kept clean. The Glass Train brought into Addison Road Station for the Exhibition, is, in a way, even more striking, as throughout it the walls, floors and ceilings are of glass. It is an exhibition in itself and includes examples of the 'Insulight' glass bricks mentioned above and of the Armour-plate glass, specially heat-treated so as to possess great fire-resisting properties with high mechanical strength. It can be bent through $30^{\circ}$ without breaking and will withstand a range of temperature from $-70^{\circ} \mathrm{C}$. to $+300^{\circ} \mathrm{C}$. The numerous fittings and other features represent nearly six hundred different varieties of glass. In another branch of industry the domestic possibilities of 'Staybrite' in pans, sinks, door furniture, toilet fittings and table-ware are demonstrated. The strength and wearing properties of this and similar materials must inevitably prove their superiority in the home. Then for the purpose of keeping food fresh and cool, one of the oldest principles for the production of long-sustained low temperature is employed in the 'Kepkold' series of coolers. By keeping the surrounding absorbent tiles supplied with water the cooling effects of evaporation are obtained without recourse to the more expensive refrigerators the utility of which depends on a supply of electricity or gas.

\section{Optical Projection of Surgical Operations}

AN optical apparatus of some interest to surgeons, devised by Profs. H. Costantini and L. Verain, of the University of Algiers, has recently been produced by the firm of Barbier Bénard and Turenne, 82 Rue Curial, Paris. It is termed a 'Scialyscope' and is a development of the shadow. less light now installed in many operating theatres. It consists essentially of a conical reflector nearly $2 \frac{1}{2}$ metres in diameter, and of roughly parabolic form, by means of which the rays from a very powerful light-source are concentrated on the field of operation. Beneath the lamp itself is placed an optical system containing a large right-angled prism by which an image of the field of operation is formed on a translucent screen in an adjoining room. The magnification on the screen is $3 \frac{1}{2}$ diameters, and the illumination is so powerful that a spectator at a distance of seven metres can obtain a brilliant view of every detail in the field of operation. There has always been very great difficulty in demonstrating operative details to a group of students; their mere presence in an operating theatre is undesirable, and it is obviously impossible for most of them to obtain any but a fleeting glimpse of what is happening. With this apparatus forty or fifty students in an adjoining room can easily follow every detail, and it will be noted that their view is obtained from a point immediately above the field of operation. By means of a microphone and a loud speaker, the surgeon can describe to them at the same time all that is being done. The method would appear to have considerable possibilities and it certainly overcomes the difficulties involved in demonstrating operative details to a number of individuals.

\section{Report of the University of Birmingham}

IN his seventeenth and last report to the Council, presented at the annual meeting of the Court of Governors of the University, the Vice-Chancellor (Sir Charles Grant Robertson) gives a summary of the progress of the University during his tenure of office. In 1920 "the high hopes, the vaulting ambitions and the dreams of a golden dawn that inspired a Great Britain freed by the Armistice from the terrors and horrors of the War slowly faded away or were frozen out, and in their place came spiritual and moral anarchy and the cynicism derisive of the past; and baffled by the present, that fears nothing but the future". Since then the University has gone rapidly forward. The income and expenditure in 1921 were $£ 143,631$ and $£ 144,535$ respectively, while for 1937 they were $£ 232,690$ and $£ 230,805$, not taking into account the sums for fellowships, scholarships and other trust funds which pass through the accounts of the University. Assets have increased to $£ 2,199,306$, and the University is free from debt, the contribu. tions to the endowment since 1920 being not less than $£ 930,000$. The grants from local authorities have increased from $£ 11,887$ to $£ 33,570$. Expenditure in stipends has increased from $£ 34,131$ to nearly $£ 100,000$. There are now 34 full-time professors and 10 part-time, while the non-professorial staff now numbers 297. The Library grant has been quintupled and the number of readers and of books taken out has increased eightfold. "The function of a university library is not merely to satisfy existing needs, but to create new appetites as yet unknown and always unpredictable; you never can tell what may result from the contact of a young mind with an adequately equipped library. In a university more minds than we are aware of are always at flash-point. It is the spark that is so often wanting.'

Sir Charles notes with satisfaction the success which has attended the large measure of self-govern. ment which has been given to the undergraduates"the student body has justified the confidence that the unification of responsibility with power demands". $\mathrm{He}$ wishes, however, that a really serious share in 